\title{
Physical and Mechanical Properties of Laminated Veneer Lumber Manufactured by Poplar Veneer
}

\author{
M. Nazerian and M. Dahmardeh Ghalehno \\ Department of Wood and Paper Science and Technology, University of Zabol, Zabol 98615-538, Iran
}

Received: May 5, 2011 / Published: November 20, 2011.

\begin{abstract}
Efficient usage of laminated veneer lumber (LVL) in the construction industry requires an understanding the effects of the heat treatment process on the physical and mechanical properties of LVL. It is well known that the heat treatment is often used to improve the dimensional stability of solid wood, but it cases to decrease mechanical properties of solid wood. However, this study aimed testing the physical and mechanical properties of LVL manufactured from heat-treated and untreated poplar veneers. The LVL samples were produced from poplar heat treated veneers (Populus nigra) in the seven ply form (3 mm each) by using urea-formaldehyde (UF) adhesive. Before manufacturing LVL, veneers were subjected to heat treatment at varying temperatures and for varying durations of heating. Significant differences were determined $(P \leq 0.05)$ in the physical and mechanical properties of the LVLs. The results were recorded the lowest density increment as $29 \%$, the lowest radial swelling as $48 \%$, the lowest tangential swelling as $45 \%$ and the lowest longitudinal swelling as $33 \%$ for LVL manufactured from heat treated veneers at $180{ }^{\circ} \mathrm{C}$ for $5 \mathrm{~h}$ as compared to the control sample. The highest flat-wise and edge-wise modulus of rupture (MOR) (107.67 MPa and 102.1 MPa) and modulus of elasticity (MOE) (6,190 MPa and 6,017 MPa) were obtained in the control sample manufactured from untreated veneers. It was determined that modulus of elasticity was less sensitive than modulus of rupture of composite lumber to change due to increase in temperature and heat durations. According to the statistical analyses of variance, the mechanical and physical properties of LVL were more sensitive to temperature than duration of exposure.
\end{abstract}

Key words: Heat treatment, laminated veneer lumber (LVL), mechanical and physical properties, Populus nigra, poplar, urea-formaldehyde (UF) adhesive.

\section{Introduction}

Durability, mechanical properties and engineering performance of LVL are affected by many factors such as wood species, heat treatment and etc [1]. One of the original reasons to heat-treat wood and wood composites is to improve the properties of durability and to obtain a more dimensionally stable material by reducing the equilibrium moisture content. It is generally accepted that heat treatment also lowers the wet ability of wood materials [2-3]. Heat treatment results in varying amounts of weight loss, depending on the treatment temperature and time. For example,

\footnotetext{
Corresponding author: M. Nazerian, Ph.D., research field: wood composite materials. E-mail: morteza17172000@yahoo.com.

M. Dahmardeh Ghalehno, M.Sc., research field: wood composite materials. E-mail: mmdahmardeh@yahoo.com.
}

weight loss of beech (Fagus sylvatica) wood, treated at increasing temperatures, was as $8.1 \%$ and $9.8 \%$ at $150{ }^{\circ} \mathrm{C}$ and $200{ }^{\circ} \mathrm{C}$, respectively [4]. Heat treatment reduces the tangential and radial swelling of wood. In general, desired changes start to appear at about $150^{\circ} \mathrm{C}$, and continue with increment in temperature in stages [5]. In bending strength, poplars compare favorably with common construction species such as pine and fir. This is especially true for oriented strand board (OSB), LVL, and structural composite lumber [6], so poplar can be used for structural and non-structural applications [7]. The LVL has been suggested as a good alternative for structural purposes. However, the results of researches about exposure durability of this material are contradictory to each other [8].

Wood and wood composites are useful 
constructional materials, but they have less desirable properties such as poor durability and poor dimensional stability. Heat treatment is an alternative method for improving these properties with no use of chemical additives. When wood is heated, chemical changes start to take place inside the wood structure. These changes result in decreased mechanical properties and increased dimensional stability. Therefore, the aim of this study was to determine the effects of heat treatment and heating duration of the veneers on the bending strength, modulus of elasticity, water absorption, and swelling of LVLs produced from poplar wood bonded with UF adhesive.

\section{Materials and Methods}

Poplar (Populus deltoids, $0.35 \mathrm{~g} \mathrm{~cm}^{-3}$ ) logs with a diameter at breast height diameter (DBH. $1.3 \mathrm{~m}$ above ground) of $38-45 \mathrm{~cm}$ were obtained from the North part of Iran. The growth rate of this material averaged 1.6 rings per centimeter. Round logs (with moisture content of $130 \%$ ) were cut into stocks without juvenile wood. After three months, veneers having dimensions of 5 $\mathrm{mm} \times 100 \mathrm{~mm} \times 360 \mathrm{~mm}$ were cut out of the stocks and were sanded on both sides with 50-grit sandpaper in belt-sanding machine. Then, veneers with dimensions of $3 \mathrm{~mm} \times 100 \mathrm{~mm} \times 360 \mathrm{~mm}$ were divided into nine treatment groups. The moisture content of the veneers before heat treatment was $8 \%$. A number of veneers were subjected to heat treatment at 80,130 and $180{ }^{\circ} \mathrm{C}$ for 1,3 , and $5 \mathrm{~h}$ in a small heating unit controlled to within $\pm 1{ }^{\circ} \mathrm{C}$ under atmospheric pressure. Before heat treatment, veneers were not dried in a dryer. After the heat treatment, the treated and untreated plies were conditioned to $12 \%$ moisture contents in a conditioning room at $23 \pm 2{ }^{\circ} \mathrm{C}$ and with $65 \pm 5 \%$ relative humidity. In order to obtain LVL with $20 \mathrm{~mm}$ thickness, 7 layers of veneers ( $3 \mathrm{~mm}$ thickness) were bonded with UF applied to one single surface of the veneer at the ratio of $180 \mathrm{~g} \mathrm{~m}^{-2}$. At first, LVL panels were prepressed in cold press and then in hot press (at $140{ }^{\circ} \mathrm{C}$ ) with pressure of $10 \mathrm{~N} \mathrm{~mm}^{-2}$ for $9 \mathrm{~min}$.
The pressed pieces of the LVLs were transformed for density, dimensional stability, modulus of elasticity and bending strength tests with finished dimensions of $20 \mathrm{~mm} \times 100 \mathrm{~mm} \times 100 \mathrm{~mm}$ and 20 $\mathrm{mm} \times 20 \mathrm{~mm} \times 360 \mathrm{~mm}$, respectively. Pressing was continued until a total of 450 samples were produced with 9 replicates for each test. Test samples were conditioned to achieve equilibrium moisture content at $23 \pm 2{ }^{\circ} \mathrm{C}$ temperature and $65 \pm 5 \%$ relative humidity prior to be tested for 2 weeks.

The dimensions and weights of the samples were measured. The air-dry density and dimensions of the samples were determined at $0.01 \mathrm{~mm}$ and $0.001 \mathrm{~g}$ sensitivity. The samples were soaked in water $(20 \pm$ $2{ }^{\circ} \mathrm{C}$ ). After $24 \mathrm{~h}$, radial swelling was measured from four different points and their average value was recorded as a single value. Also, the tangential and longitudinal swellings of the samples were calculated as a percentage. For static bending test, the samples were destructively tested in both flat-wise and edge-wise bending according to the ISO 16978 standards [9]. The loading speed was $1 \mathrm{~mm} / \mathrm{min}$.

For air-dry density, radial (thickness), tangential and longitudinal swelling, edge-wise and flat-wise MOR and MOE, all multiple comparisons were first subjected to an analysis of variance (ANOVA) and significant differences between mean values of control and treated samples were determined using Duncan's multiple range test. The significance of results was at $5 \%$. The $t$-test with Bonferroni correction was used to determine whether or not the differences between the flat-wise and edge-wise MOR and MOE values according to the treatment temperature and time were significant.

\section{Results and Discussion}

Table 1 shows the values of the air-dry density, radial, tangential and longitudinal swelling of LVL manufactured from veneers treated under different treatment regimes. According to the averages, the physical properties decreased with increasing temperature and duration of heating time. The result 
Table 1 The effect of heat treatment of veneers for different durations heating on physical and mechanical properties of the LVL.

\begin{tabular}{|c|c|c|c|c|c|c|c|c|c|c|}
\hline \multirow{2}{*}{$\begin{array}{l}\text { Heat } \\
\text { treatment }\end{array}$} & \multirow{2}{*}{$\begin{array}{l}\text { Time } \\
\text { (h) }\end{array}$} & \multirow[b]{2}{*}{ Unit } & \multirow{2}{*}{$\begin{array}{l}\text { Air-dry } \\
\text { density } \\
\left(\mathrm{gcm}^{-3}\right)\end{array}$} & \multicolumn{3}{|c|}{ Swelling } & \multicolumn{4}{|c|}{ Mechanical properties } \\
\hline & & & & Radial & Tangential & Longitudinal & $\begin{array}{l}\mathrm{I}_{\mathrm{MOR}} \\
(\mathrm{MPa})\end{array}$ & $\begin{array}{l}\perp_{\mathrm{MOE}} \\
(\mathrm{MPa})\end{array}$ & $\begin{array}{l}\| \mathrm{MOR} \\
(\mathrm{MPa})\end{array}$ & $\begin{array}{l}\mid \begin{array}{l}\mid \mathrm{MOE} \\
(\mathrm{MPa})\end{array} \\
\end{array}$ \\
\hline \multirow[t]{2}{*}{ Control } & & Mean & $\pm 0.42 \mathrm{~A}$ & $12.18 \mathrm{~A}$ & $6.71 \mathrm{~A}$ & $0.97 \mathrm{~A}$ & $107.67 \mathrm{~A}$ & $6,190 \mathrm{~A}$ & $102.1 \mathrm{~A}$ & $6,017 \mathrm{~A}$ \\
\hline & & $\mathrm{sd}$ & 0.0036 & 0.40 & 0.51 & 0.005 & 9.5 & 42 & 9 & 72 \\
\hline \multirow[t]{6}{*}{$80^{\circ} \mathrm{C}$} & 1 & Mean & $\pm 0.42 \mathrm{~A}$ & $11.55 \mathrm{~A}$ & $6.71 \mathrm{~A}$ & $0.98 \mathrm{~A}$ & $103.55 \mathrm{~A}$ & $6,168.3 \mathrm{~A}$ & $95.8 \mathrm{~B}$ & $6,010 \mathrm{~A}$ \\
\hline & & $\mathrm{sd}$ & 0.0054 & 0.27 & 0.59 & 0.005 & 6.3 & 68.8 & 5.8 & 85.4 \\
\hline & 3 & Mean & $\pm 0.417 \mathrm{~A}$ & $11.47 \mathrm{~A}$ & $6.57 \mathrm{~A}$ & $0.96 \mathrm{~A}$ & $89.7 \mathrm{~B}$ & $6,012.2 \mathrm{~B}$ & $82.5 \mathrm{C}$ & $5,971.1 \mathrm{~A}$ \\
\hline & & sd & 0.0068 & 0.76 & 0.51 & 0.004 & 5.1 & 59.9 & 5.4 & 26.4 \\
\hline & 5 & Mean & $\pm 0.417 \mathrm{~B}$ & $10.28 \mathrm{~B}$ & $6.49 \mathrm{~A}$ & $0.96 \mathrm{~A}$ & $78.4 \mathrm{C}$ & $5,894.3 \mathrm{C}$ & $74.8 \mathrm{D}$ & $5,773.8 \mathrm{~B}$ \\
\hline & & $\mathrm{sd}$ & 0.0052 & 0.85 & 0.28 & 0.003 & 8.5 & 93.1 & 9.9 & 71.4 \\
\hline \multirow[t]{6}{*}{$130^{\circ} \mathrm{C}$} & 1 & Mean & $\pm 0.362 \mathrm{~B}$ & $9.79 \mathrm{BC}$ & $5.61 \mathrm{~B}$ & $0.87 \mathrm{~B}$ & $56.4 \mathrm{D}$ & $5,842.9 \mathrm{C}$ & $51.7 \mathrm{E}$ & $5,792.3 \mathrm{~B}$ \\
\hline & & $\mathrm{sd}$ & 0.0054 & 1.04 & 0.30 & 0.003 & 3.7 & 39.51 & 51.7 & 73.56 \\
\hline & 3 & Mean & $\pm 0.362 \mathrm{~B}$ & $9.18 \mathrm{CD}$ & $5.35 \mathrm{~B}$ & $0.86 \mathrm{~B}$ & $54.5 \mathrm{D}$ & $5,330 \mathrm{D}$ & $50.5 \mathrm{E}$ & $5,272.7 \mathrm{C}$ \\
\hline & & sd & 0.0065 & 1.08 & 0.34 & 0.004 & 7.3 & 52.2 & 7.1 & 39.8 \\
\hline & 5 & Mean & $\pm 0.36 \mathrm{C}$ & $9.46 \mathrm{C}$ & $5.26 \mathrm{~B}$ & $0.85 \mathrm{C}$ & $34.8 \mathrm{E}$ & $5,266.7 \mathrm{DE}$ & $31.1 \mathrm{E}$ & $5,233.4 \mathrm{C}$ \\
\hline & & sd & 0.01 & 0.97 & 0.81 & 0.005 & 3.7 & 35.9 & 4.3 & 38.8 \\
\hline \multirow[t]{6}{*}{$180^{\circ} \mathrm{C}$} & 1 & Mean & $\pm 0.334 \mathrm{D}$ & $8.55 \mathrm{DE}$ & $4.67 \mathrm{C}$ & $0.71 \mathrm{D}$ & $54.3 \mathrm{D}$ & $5,193.8 \mathrm{E}$ & $49 \mathrm{~F}$ & $4,504.7 \mathrm{D}$ \\
\hline & & $\mathrm{sd}$ & 0.0035 & 0.81 & 0.51 & 0.004 & 3.7 & 308.8 & 5.2 & 58.8 \\
\hline & 3 & Mean & $\pm 0.32 \mathrm{D}$ & $7.83 \mathrm{E}$ & $4.43 \mathrm{C}$ & $0.70 \mathrm{D}$ & $26.9 \mathrm{~F}$ & $4,998.2 \mathrm{~F}$ & $24.3 \mathrm{G}$ & $4,359 \mathrm{E}$ \\
\hline & & sd & 0.0052 & 0.73 & 0.36 & 0.009 & 4.5 & 48.8 & 3.4 & 64.9 \\
\hline & 5 & Mean & $\pm 0.298 \mathrm{D}$ & $6.33 \mathrm{~F}$ & $3.64 \mathrm{D}$ & $0.65 \mathrm{E}$ & $20.9 \mathrm{G}$ & $4,265.7 \mathrm{G}$ & $16.7 \mathrm{H}$ & $3,943 \mathrm{~F}$ \\
\hline & & sd & 0.005 & 0.54 & 0.24 & 0.013 & 5.3 & 34.2 & 5.2 & 84.7 \\
\hline
\end{tabular}

Groups with same letters in column indicate that there was no statistical difference $(P<0.01)$ between the samples according to Duncan's multiple range test. $\perp$ : flat-wise modulus of rupture and elasticity; $\|$ : edge-wise modulus of rupture and elasticity.

of ANOVA proved that the effect of temperature and duration of heating time on air-dry densities of LVL panels was significant with 0.05 probabilities. The air-dry density values of LVLs decreased with increasing temperature and heat treatment time of veneers under the mentioned conditions. The LVL made from heat treated veneers at a temperature of $180{ }^{\circ} \mathrm{C}$ for $5 \mathrm{~h}$ showed the lowest air-dry density values $\left(0.298 \mathrm{~g} \mathrm{~cm}^{-3}\right)$. In contrast, the LVL manufactured from untreated veneers had the highest air-dry density $\left(0.42 \mathrm{~g} \mathrm{~cm}^{-3}\right)$. Both LVL of heat treated veneers (at $80^{\circ} \mathrm{C}$ and $130{ }^{\circ} \mathrm{C}$ ) and untreated veneers had higher density values than those of solid wood from which LVLs were produced. The reason for higher density of the mentioned LVLs is related to the thickness loss of the panel due to the compression rate during pressing and the higher density of adhesive being used in panel production. Esteves et al. [10] studied the mass loss of heat treated maritime pine at temperatures between $170{ }^{\circ} \mathrm{C}$ and $200{ }^{\circ} \mathrm{C}$ during 2 to 24 hours and concluded that the mass loss increases with the treatment time and with the temperature, and the same mass loss can be obtained with different temperatures, depending on the treatment time.

The control sample had the highest average thickness, tangential and longitudinal swellings of $12.18 \%, 6.71 \%$ and $0.97 \%$, respectively. The LVL with treated veneers at $80{ }^{\circ} \mathrm{C}$ for 1,3 and $5 \mathrm{~h}$ had somewhat lower average swellings than others. The LVLs with heat-treated veneers at 130 and $180{ }^{\circ} \mathrm{C}$ for $5 \mathrm{~h}$ were found to have significantly lower average radial, tangential and longitudinal swellings. The highest decreases in swelling to radial, tangential and longitudinal directions were found to be $48 \%, 45 \%$ and $33 \%$, respectively (Table 2), in the LVLs made from veneers treated at $180{ }^{\circ} \mathrm{C}$ for $5 \mathrm{~h}$. Zivkovic et al. [11] showed that higher level of treatment temperatures yields proportionally greater stabilization effects. They obtained that the heat treated wood, when compared to genuine wood, exhibits a significant reduction of fibre saturation point and improvements in dimensional stability. The change in the physical properties was mainly influenced by the value of density of the LVL and thermal degrading of hemicelluloses. Theoretically, 
Table 2 Percentage decrease of swellings and mechanical properties in LVL manufactured from poplar veneer following heat treatment for different durations.

\begin{tabular}{|c|c|c|c|c|c|c|c|c|c|}
\hline \multirow[b]{2}{*}{$\begin{array}{l}\text { Temperature } \\
\left({ }^{\circ} \mathrm{C}\right)\end{array}$} & \multirow[b]{2}{*}{$\begin{array}{l}\text { Time } \\
\text { (h) }\end{array}$} & \multirow[b]{2}{*}{$\begin{array}{l}\text { Air-dry } \\
\text { density (\%) }\end{array}$} & \multicolumn{3}{|c|}{ Swelling } & \multicolumn{4}{|c|}{ Mechanical properties } \\
\hline & & & Radial (\%) & $\begin{array}{l}\text { Tangential } \\
(\%)\end{array}$ & $\begin{array}{l}\text { Longitudinal } \\
(\%)\end{array}$ & $\begin{array}{l}\perp_{\mathrm{MOR}} \\
(\%)\end{array}$ & $\begin{array}{l}\perp_{\mathrm{MOE}} \\
(\%)\end{array}$ & $\begin{array}{l}\| \text { MOR } \\
(\%)\end{array}$ & $\begin{array}{l}\| \mathrm{MOE} \\
(\%)\end{array}$ \\
\hline \multirow[t]{3}{*}{$80^{\circ} \mathrm{C}$} & 1 & 0.6 & 5.0 & 0 & 0 & 4 & 0.35 & 6 & 0.1 \\
\hline & 3 & 1.1 & 5.5 & 1.5 & 0.8 & 17 & 2.80 & 19 & 0.8 \\
\hline & 5 & 1.2 & 15.6 & 2.7 & 0.8 & 27 & 4.80 & 27 & 4.0 \\
\hline \multirow[t]{3}{*}{$130^{\circ} \mathrm{C}$} & 1 & 14 & 19.5 & 16 & 10.6 & 47 & 5.60 & 50 & 3.7 \\
\hline & 3 & 15 & 25.3 & 20 & 11.3 & 49 & 13.9 & 51 & 12 \\
\hline & 5 & 14 & 22.0 & 21 & 13.4 & 67 & 14.9 & 69 & 13 \\
\hline \multirow[t]{3}{*}{$180^{\circ} \mathrm{C}$} & 1 & 21 & 30.0 & 30 & 27.0 & 49 & 16.1 & 52 & 25 \\
\hline & 3 & 24 & 36.0 & 33 & 28.0 & 75 & 19.2 & 76 & 27 \\
\hline & 5 & 29 & 48.0 & 45 & 33.0 & 81 & 31.0 & 84 & 34 \\
\hline
\end{tabular}

$\perp$ : flat-wise modulus of rupture and elasticity; $\|$ : edge-wise modulus of rupture and elasticity.

the available $\mathrm{OH}$ groups in hemicellulose have the most significant effect on the physical properties of wood. Heat treatment slowed water uptake and lowered water absorption by wood cell wall because of decrease in the amount of $\mathrm{OH}$ groups. As a consequence of the reduced number of hydroxyl groups, the swelling and shrinking became lower $[12,13]$. These finding suggest that improvement of physical behavior of LVL produced from poplar veneers can be achieved by using heat treatment. The increase in dimensional stability for heat treated woods mainly is due to the decrease of hygroscopicity in view of the chemical changes at high temperatures. The decrease rates for arabinose, galactose, xylose, and mannose indicate that the high temperature decreases the equilibrium moisture of veneer and consequently the swelling of panels made of veneers [14]. Zhang et al. [15] showed that changing the character of wood from hydrophilic to more hydrophobic by hemicellulose extraction can also potentially improve dimensional stability in wood and wood-based composites. Also, Ates et al. [16] reported that all values of the physical properties were decreased with temperature and duration of process, and physical properties were strongly affected negatively by treatment temperature. They concluded that this result can be explained in terms of material losses in cell wall and hemicelluloses degradation depending on the applied high temperature after heat treatment.

The effect of temperature and heat durations on the mechanical properties of LVL was significant $(P \leq$
0.05) for flat-wise and edge-wise MOR and MOE (Table 1). The flat-wise MOR and MOE were lowest in laminated poplar manufactured from heat treated veneers at $180{ }^{\circ} \mathrm{C}$ during $5 \mathrm{~h}$ with $20.9 \mathrm{MPa}$ and 4,265.7 $\mathrm{MPa}$, followed by LVL produced from the treated veneers at $180{ }^{\circ} \mathrm{C}$ during $3 \mathrm{~h}$. The flat-wise MOR and MOE values in LVL produced from the heat treated veneers at $180{ }^{\circ} \mathrm{C}$ during $5 \mathrm{~h}$ were $81 \%$ and $31 \%$, respectively, lower than control samples (Table 2). Therefore, decreases of flat-wise static bending strength reached with increasing thermal treatment conditions. The highest flat-wise MOR and MOE values (107.67 $\mathrm{MPa}$ and $6190 \mathrm{MPa})$ were obtained in the laminated poplar with untreated veneers, followed by MOR and MOE of samples with treated veneers at $80^{\circ} \mathrm{C}$ for $1 \mathrm{~h}$.

The most decrease in edgewise MOR and MOE values of laminated poplar were observed at $16.7 \mathrm{MPa}$ and 3,943 $\mathrm{MPa}$ when poplar veneers were treated at $180^{\circ} \mathrm{C}$ for $5 \mathrm{~h}$. The edge-wise MOR and MOE of LVL panels with veneers treated at $180{ }^{\circ} \mathrm{C}$ for $5 \mathrm{~h}$ were $84 \%$ and 34\%, respectively, which were significantly $(P \leq$ 0.05 ) lower than that of control sample (Table 2). These results can be explained with material loses in cell lumen and hemicellulose degradation due to applied height temperature [17]. Control sample had the highest edge-wise MOR and MOE (102.1 MPa and 6,017 $\mathrm{MPa}$ ), which followed by LVL made from veneers treated at $80^{\circ} \mathrm{C}$ for $1 \mathrm{~h}$ with MOR and MOE of $95.8 \mathrm{MPa}$ and $6,010 \mathrm{MPa}$, respectively. On the other 
hand, a slight increase in MOR and MOE were observed on samples with veneers treated at $80{ }^{\circ} \mathrm{C}$ for 1,3 and $5 \mathrm{~h}$, respectively. In this case, temperature might have greater influence on strength properties than time. The strength of the laminated poplar was higher than that of solid poplar, but a dramatic diminution was observed above temperatures of about $180{ }^{\circ} \mathrm{C}$. Similar results were reported by the other researchers in solid wood [18]. This research approved that the MOR and MOE of poplar LVLs were higher than those of corresponding solid materials. The increase is assumed to be due to glue usage and layered structure. One of the major problems is strength losses explained by thermal degradation rate and material loss [19]. The overall results in the strength on the laminated poplar tests for both the MOR and MOE seem to be greatly influenced by the combined densities of the laminated veneer, treatment temperature and treatment time. These values increase with the increases in density of the LVL. The strength of laminated wood decreases when wood is heated and increases when it is cooled. This effect was clearly achieved with the prolonged treatments. The least property affected was the MOE while the most affected one was the MOR (Table 2). This finding supports previous research that heat treatment causes important degradations of the material, resulting in a decrease of the hemicellulose content $[10,14,15]$.

The diminutions in the strength properties are related to the rate of thermal degradation and losses of substance after the heat treatments. The decrease in strength is mainly due to the depolymerization reactions of wood polymers [20]. The primary reason for the strength loss is degradation of hemicelluloses, which is less stable to heat than cellulose and lignin. Changes or losses of hemicelluloses play key roles in strength properties of wood heated at high temperatures [21]. Nazerian et al. [14] reported that the decrease rates for arabinose, galactose and mannose at $180{ }^{\circ} \mathrm{C}$ heated wood veneers when compared to untreated veneers are remarkable. Arabinose, mannose, galactose and xylose, which are responsible for hemicelluloses formation [22], were significantly influenced by increasing temperatures. Higashihara et al. [23] found that hemicelluloses began to measurably degrade after steaming for $60 \mathrm{~min}$ and both hemicelluloses and cellulose were considerably decreased after $720 \mathrm{~min}$ of heating at $180{ }^{\circ} \mathrm{C}$. Gunduz et al. [12] showed that density, swelling and compression strength values decreased with increasing treatment temperature and treatment times. It was determined that the smallest decrease was observed in the treatment at $120{ }^{\circ} \mathrm{C}$ for $2 \mathrm{~h}$. Kol [24] observed decreases of $13.1 \%$ and $9.5 \%$ in the MOE and 59.5 and $10.5 \%$ in the MOR of heat treated at $212{ }^{\circ} \mathrm{C}$ for pine and fir, respectively. In this study, the decrease in MOE was lower than MOR. Korkut [25] reported a decrease in MOE of $35 \%$ and in MOR of $16 \%$ at $180{ }^{\circ} \mathrm{C}$ for oven heat treated fir for $2 \mathrm{~h}$. These changes were higher than our results though the same wood species was used.

According to the test results, the differences between the edge-wise and flat-wise MOR and MOR values were insignificant for all of the test samples. Consequently, the loading direction in the laminated structural elements was not generally influential in bending strength and modulus of elasticity.

\section{Conclusion}

The results showed that the density, swelling, flat-wise and edge-wise bending strength and modulus of elasticity of the LVL manufactured from heat treated poplar veneers decreased for all treatment. Higher weight decrease was obtained from the LVL with veneers treated at $180{ }^{\circ} \mathrm{C}$. The highest decrement in the radial, tangential and longitudinal swelling was determined in the LVL made from veneers heat treated at $180{ }^{\circ} \mathrm{C}$ for $5 \mathrm{~h}$. In the radial, tangential and longitudinal swelling, the values of LVL produced from untreated plies were higher than the values of LVL produced from heat treated plies.

The flat-wise and edge-wise MOE of LVL with veneers treated at $180{ }^{\circ} \mathrm{C}$ has lower values than other treatments. The highest increase in flat-wise and edge-wise MOE tests was determined at the LVL with 
untreated veneers. Based on the findings in this study, edge-wise bending strength and modulus of elasticity tested decreased with increasing in temperature and time.

The improved characteristics in swelling of LVL made from heat treated plies have to be balanced against the decrease in strength values when evaluating the effectiveness of using this treatment. Consequently, the evaluated results indicated that increase of the temperature and treatment time resulted in better dimension stability for the LVLs.

\section{References}

[1] P.S. Hing, M.T. Paridah, A. Zakiah, Edgewise bending properties of LVL: effects of veneer thickness and species, in: The Proceedings of USM-JIRCAS Joint International Symposium, Lignocellulose-Material of the Millennium: Technology and Application, 2001, pp. 20-22.

[2] M. Petrissans, P. Gerardin, E.I. Bakali, M. Serraj, Wettability of heat treated wood, Holzforsch. 57 (2003) 301-307.

[3] P. Gerardin, M. Petric, M. Petrissans, J. Lambert, J.J. Ehrhrardt, Evolution of wood surface free energy after heat treatment, Polym. Degrad. Stabil. 92 (2007) 653-657.

[4] D. Fengel, G. Wegener, Wood Chemistry, Ultrastructure, Reactions, Walter de Gruyter and Co., Berlin, New York, 1989, p. 613.

[5] Finnish Thermo Wood Association, Thermo Wood Handbook, Helsinki, Finland, 2003.

[6] B. English, A.J. Youngquist, A.M. Krzysik, Cellulosic Polymers, Blends and Composites, Chapter 6, Lignocellulosic Composites, Hanser Publishers, New York, 1994, pp. 115-130.

[7] H. Keskin, M. Atar, Comparison of some technological properties of (5 layers) wood laminations centred with poplar, Gazi University J. Sci. 18 (2005) 115-126.

[8] D.W. Green, J.W. Evans, Flexural properties of structural lumber products after long-term exposure to $150{ }^{\circ} \mathrm{F}$ and $75 \%$ relative humidity, in: The Proceedings of 35 th International Particleboard Composites Materials Symposium, Washington State University, Washington, USA, 2005, pp. 3-14.

[9] ISO 16978, Wood-Based Panels-Determination of Modulus of Elasticity in Bending and of Bending Strength, 2003.

[10] B.M. Esteves, I.J. Domingos, H.M. Pereira, Pine wood modification by heat treatment in air, BioResources 3 (2008) 142-154.

[11] V. Zivkovic, I. Prsa, H. Turkulin, T. Sinkovic, V.J. Rajkovic, Dimensional stability of heat treated wood floorings, Drvna Industrija 59 (2008) 69-73.

[12] G. Gunduz, S. Korkut, D.S. Korkut, The effects of heat treatment on physical and technological properties and surface roughness of Camiyanı Black Pine (Pinus nigra Arn. subsp. pallasiana var. pallasiana) wood, Bioresource Technology 99 (2008) 2275-2280.

[13] V.M. Tuong, J. Li, Effect of heat treatment on the change in color and dimensional stability of acacia hybrid wood, BioResources 5 (2010) 1257-1267.

[14] M. Nazerian, M. Dahmardeh Ghalehno, A. Bayat Kashkooli, Effect of wood species, amount of juvenile wood and heat treatment on mechanical and physical properties of laminated veneer lumber, Journal of Applied Sciences 11 (2011) 980-987.

[15] Y. Zhang, O. Hosseinaei, S. Wang, Z. Zhou, Influence of hemicellulose extraction on water uptake behavior of wood strands, Wood and Fiber Science 43 (2011) 1-7.

[16] S. Ates, M.H. Akyildiz, H. Ozdemir, Effects of heat treatment on calabrian pine (Pinus brutia Ten.) wood, BioResources 4 (2009) 1032-1043.

[17] S. Yildiz, Physical, mechanic, technologic and chemical properties of Fagus orientalis and Picea orientalis wood treated by heating, Ph.D. Thesis, K.T.U. Institute of Science and Technology, Trabzon, 2002.

[18] S. Yildiz, E.D. Gezer, U.C. Yildiz, Mechanical and chemical behavior of spruce wood modified by heat, Building and Environment 41 (2006) 1762-1766.

[19] H. Rusche, Thermal degradation of wood at temperatures up to $200{ }^{\circ} \mathrm{C}$ : Part I. Strength properties of dried wood after heat treatment, Holz als Roh- und Werkstoff 31 (1973) 273-281.

[20] R. Kotilainen, Chemical changes in wood during heating at $150-260^{\circ} \mathrm{C}, \mathrm{Ph} . \mathrm{D}$. Thesis, Jyvä skylä University, Res. Report 80, Finland, 2000.

[21] W. Hillis, Wood quality and utilization, in: W.E. Hillis, A.G. Brown (Eds.), Eucalypts for Wood Production, CSIRO, Melbourne, 1984, pp. 259-289.

[22] R.M. Rowell, R. Pettersen, J.S. Han, J.S. Rowell, M.A. Tshabalala, Cell wall chemistry, in: R.M. Rowell (Ed.), Handbook of Wood Chemistry and Wood Composites, 2005, pp. 35-74.

[23] T. Higashhara, T. Morooka, S. Hirosawa, M. Norimota. Relationship between changes in chemical components and permanent fixation of compressed wood by steaming and heating, J. Japanese Wood Research Society 50 (2004) 159-167.

[24] H.S. Kol, Characteristics of heat-treated Turkish pine and fir wood after thermo wood processing, Journal of Environmental Biology 31 (2010) 1007-1011.

[25] S. Korkut, The effects of heat treatment on some technological properties in Uludag fir (Abies bornmullerinana Mattf.) wood, Build Environ. 43 (2008) 422-428. 